\title{
Proteome Profiling of the Exhaled Breath Condensate after Long-Term Spaceflights
}

\author{
Alexey S. Kononikhin 1,2,*(1), Alexander G. Brzhozovskiy ${ }^{1,2}$, Anna M. Ryabokon ${ }^{3,4}$, \\ Kristina Fedorchenko ${ }^{3,4}$ (D), Natalia V. Zakharova ${ }^{3}$, Alexander I. Spasskii ${ }^{5}$, Igor A. Popov ${ }^{5,6}$, \\ Vyacheslav K. Ilyin ${ }^{2}$, Zoya O. Solovyova ${ }^{2}$, Lyudmila Kh. Pastushkova ${ }^{2}$, Alexey V. Polyakov ${ }^{2}$, \\ Sergey D. Varfolomeev ${ }^{3,4}$, Irina M. Larina ${ }^{2, *}$ and Evgeny N. Nikolaev ${ }^{1, *}$ \\ 1 Laboratory of mass spectrometry, CDISE, Skolkovo Institute of Science and Technology, \\ 121205 Moscow, Russia \\ 2 Russian Federation State Scientific Research Center Institute of Biomedical Problems, \\ Russian Academy of Sciences, 119991 Moscow, Russia \\ 3 Emanuel Institute for Biochemical Physics, Russian Academy of Sciences, 119991 Moscow, Russia \\ 4 Department of Chemistry, Lomonosov Moscow State University, 119991 Moscow, Russia \\ 5 V.L. Talrose Institute for Energy Problems of Chemical Physics, N.N. Semenov Federal Center of Chemical \\ Physics, Russian Academy of Sciences, 119334 Moscow, Russia \\ 6 Laboratory of Ion and Molecular Physics, Moscow Institute of Physics and Technology, Dolgoprudny, \\ 141701 Moscow, Russia \\ * Correspondence: alex.kononikhin@gmail.com (A.S.K.); irina.larina@gmail.com (I.M.L.); \\ ennikolaev@gmail.com (E.N.N.)
}

Received: 21 July 2019; Accepted: 10 September 2019; Published: 12 September 2019

\begin{abstract}
Comprehensive studies of the effects of prolonged exposure to space conditions and the overload experienced during landing on physiological and biochemical changes in the human body are extremely important in the context of planning long-distance space flights, which can be associated with constant overloads and various risk factors for significant physiological changes. Exhaled breath condensate $(\mathrm{EBC})$ can be considered as a valuable subject for monitoring physiological changes and is more suitable for long-term storage than traditional monitoring subjects such as blood and urine. Herein, the EBC proteome changes due to the effects of spaceflight factors are analyzed. Thirteen EBC samples were collected from five Russian cosmonauts (i) one month before flight (background), (ii) immediately upon landing modules in the field (R0) after 169-199 days spaceflights, and (iii) on the seventh day after landing $(\mathrm{R}+7)$. Semi-quantitative label-free EBC proteomic analysis resulted in 164 proteins, the highest number of which was detected in EBC after landing (R0). Pathways enrichment analysis using the GO database reveals a large group of proteins which take part in keratinization processes (CASP14, DSG1, DSP, JUP, and so on). Nine proteins (including KRT2, KRT9, KRT1, KRT10, KRT14, DCD, KRT6C, KRT6A, and KRT5) were detected in all three groups. A two-sample Welch's $t$-test identified a significant change in KRT2 and KRT9 levels after landing. Enrichment analysis using the KEGG database revealed the significant participation of detected proteins in pathogenic E. coli infection (ACTG1, TUBA1C, TUBA4A, TUBB, TUBB8, and YWHAZ), which may indicate microbiota changes associated with being in space. This assumption is confirmed by microbial composition analysis. In general, the results suggest that $\mathrm{EBC}$ can be used for noninvasive monitoring of health status and respiratory tract pathologies during spaceflights, and that the obtained data are important for the development of medicine for use in extreme situations. Data are available from ProteomeXchange using the identifier PXD014191.
\end{abstract}

Keywords: spaceflight; exhaled breath condensate; proteomics; mass-spectrometry; astronauts; extreme conditions 


\section{Introduction}

Space flight is one of the most extreme conditions encountered by humans. The combined effect of factors such as radiation, microgravity, hypodynamia, and isolation disturb homeostatic systems and affect a majority of physiological systems [1,2]. The factors associated with hypogravity during a prolonged space flight leads to the restructuring of all body systems, towards a new level of functioning, which includes a decrease in bone and muscle tissue, the redistribution of bodily fluids, and a number of other physiological changes that cannot be accompanied by changes in the regulation of vital activity, including gene expression and protein synthesis [3]. The monitoring of changes in individual physiological and biochemical characteristics is of particular importance for the development of personalized countermeasures, in order to minimize the risks associated with being in space, and many experimental tools and methods have been developed to study space-induced physiological changes [4]. The increased background radiation was shown by NASA and Roscosmos researchers to be one of the primary risk factors for the health of astronauts, which, together with constant overloads and age factors, increases the risk of developing cardiovascular diseases and oncology [5-7]. The Human proteomics at Extreme Conditions Initiative started in 2013 as an international collaborative initiative aiming to accumulate proteomic data on the effects of space flight factors on the human body, including both real space missions and ground-based model experiments (https://hupo.org/Human-Proteomics-at-Extreme-Conditions). However, to date, the study of proteomic space-flight associated changes have mostly been limited to the models of cultured cells, plants, Micro-organisms, and animals of various taxonomic groups [8-12]. Therefore, the study of spaceflight effects on changes in the human proteome remains very relevant.

Blood and urine are the primary traditional subjects for the screening of physiological changes associated both with various diseases, and with extreme conditions or environmental factors [13,14]. However, the proteome of these samples collected in space cannot be analyzed in short time, and long-term storage significantly reduces their nativeness. Exhaled breath condensate (EBC) is another biological fluid which can be collected noninvasively, as frequently as necessary, and can be stored at $-80{ }^{\circ} \mathrm{C}$ for up to 8 months [15]. As respiratory function is vital, and both lifestyle and health status significantly affect the state of the respiratory system, EBC can be an essentially important subject for monitoring physiological changes, providing valuable information for rapid diagnostics of the state of the respiratory system state [16-19]. It typically includes up to 2000 compounds of various classes, including proteins, lipids, antibodies, carbohydrates, amino acids, and other non-volatile biomacromolecules [17,20,21]. Currently, nitrous oxide (NO) [22-25], hydrogen peroxide $\left(\mathrm{H}_{2} \mathrm{O}_{2}\right)$ [26-29], and acetone are conventional and FDA-approved markers for the diagnosis of inflammatory processes in the respiratory system. Lipid components, steroids, eicosanoids, and their subclasses of prostaglandins and isoprostanes have been shown to be possible markers of various pathologies [30,31]. In particular, 8-isoprostane is considered to be a biomarker of oxidative stress [32] and the $\mathrm{pH}$ of EBC can be considered as a simple but reliable biomarker of various lung diseases [33-35]. A number of proteins including cytokeratins (1, 5, 9, and 14), C-reactive protein, interleukins (IL-1 $\alpha$, IL-1 $\beta$, IL-2, IL-12 $\alpha$, IL-12 $\beta$, and IL-15), tumor necrosis factor- $\alpha$, C3 complement component, and interferons $\alpha$ and $\gamma$, as well as proteome profiles have been shown to be characteristic for particular pathologies, including asthma, chronic obstructive pulmonary disease, lung cancer, and so on [36-38]. However, most useful for the present study is the fact that EBC composition reflects the real-time state of the respiratory system. As the conditions of space flight and landing create an extraordinary load, the systemic changes in the human organism can also affect the composition of the EBC, including its proteome [4].

In this study, a comparative semi- quantitative label-free EBC proteome analysis of samples collected from cosmonauts before and after long-term space flights was performed. The results suggest that EBC analysis may provide important information on systemic changes in the human organism, and can be used for noninvasive monitoring of the health status and respiratory tract pathologies of astronauts during the spaceflight. 


\section{Results and Discussion}

A semi-quantitative label-free proteomic analysis of 13 EBC samples collected from five Russian cosmonauts before and after long-term (169-199 days) spaceflights was performed. EBC samples were collected at the Yu. A. Gagarin Research and Test Cosmonaut Training Center one month before flight (background), immediately after landing (R0), and on the seventh day after landing (R+7). LC-MS/MS analysis resulted in 164 different proteins. To analyze the correlation between samples and technical runs, Pearson's coefficient was calculated. It showed good correlation (about 0.9) between sample runs and an acceptable correlation for inter-individual variability in the groups of samples. The distribution of the number of identified proteins between the background and R7 samples is presented in the Venn diagram (Figure 1).

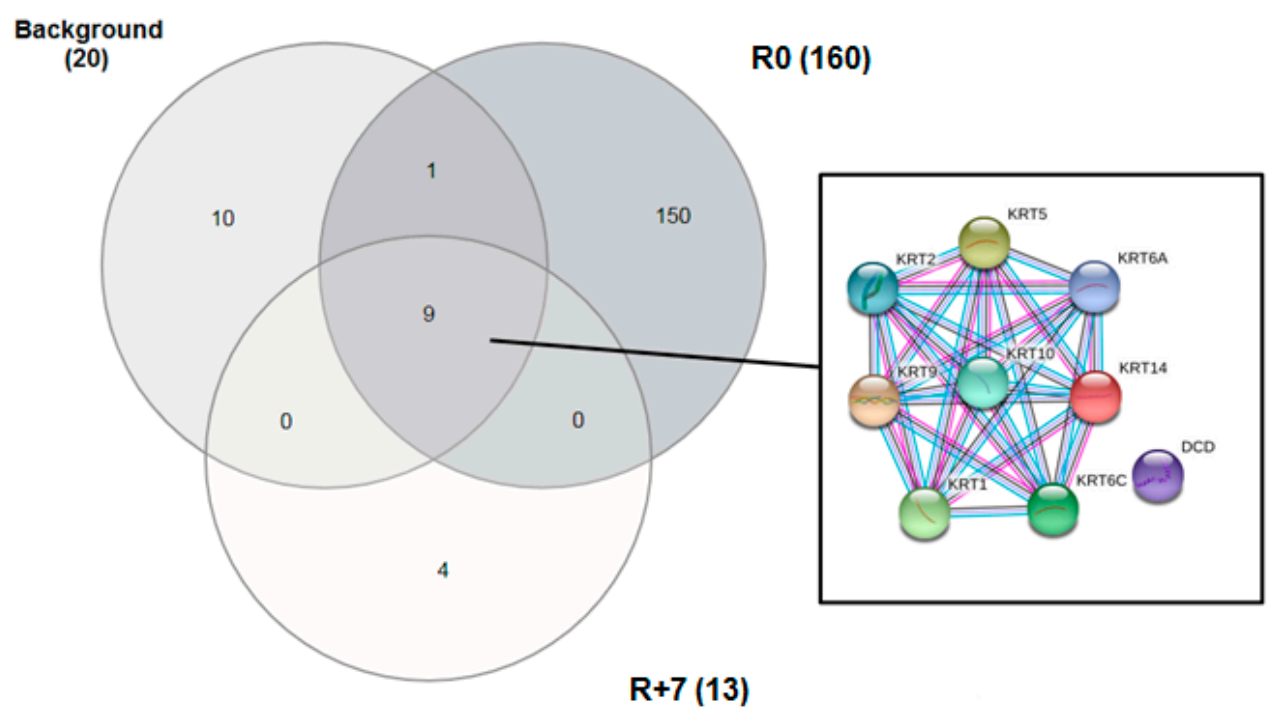

Figure 1. Venn diagram of 164 proteins identified in exhaled breath condensate (EBC) samples in three different groups: Background (1 month before landing), R0 (immediately after landing) and R+7 (seventh day after landing). For the 9 proteins detected in all groups, a STRING proteins interaction network is presented: Purple indicates experimentally determined interactions, blue indicates interactions from the curated database and black indicates co-expression of genes.

Nine proteins (KRT2, KRT9, KRT1, KRT10, KRT14, DCD, KRT6C, KRT6A, and KRT5) were detected in all groups (Table 1). Interaction analysis using the STRING database [39] showed that eight of the proteins belong to intermediate and keratin filaments. KRT14, KRT2, KRT5, KRT6A, and KRT9 function as structural constituents of the cytoskeleton and KRT1, KRT10, and KRT2 are structural constituents of epidermis. Analysis of proteome composition shows that the highest number of proteins was detected in the R0 group (Figure 1, Supplementary table).

Table 1. List of proteins belongs to keratins family presented in three study groups: background (month before flight), R0, and $\mathrm{R}+7$ groups.

\begin{tabular}{|c|c|c|c|c|c|c|}
\hline Protein IDs & Protein Names & $\begin{array}{c}\text { Gene } \\
\text { Names }\end{array}$ & Background & $\begin{array}{l}1 \text { Day After } \\
\text { Landing }\end{array}$ & $\begin{array}{l}7 \text { Day After } \\
\text { Landing }\end{array}$ & Peptides \\
\hline P04264 & Keratin, type II cytoskeletal 1 & KRT1 & $17.6 \pm 1.5$ & $18.4 \pm 0.3$ & $17.8 \pm 0.6$ & 34 \\
\hline P13645 & Keratin, type I cytoskeletal 10 & KRT10 & $16.2 \pm 1.4$ & $18.2 \pm 0.4$ & $16.1 \pm 1.3$ & 30 \\
\hline P02533 & Keratin, type I cytoskeletal 14 & KRT14 & $15.4 \pm 0.1$ & $15.1 \pm 1.4$ & $14.5 \pm 0.1$ & 23 \\
\hline P35908 & Keratin, type II cytoskeletal 2 epidermal & KRT2 & $16 \pm 0.2$ & $17 \pm 0.4$ & $15.4 \pm 0.9$ & 29 \\
\hline P13647 & Keratin, type II cytoskeletal 5 & KRT5 & $14.1 \pm 0.2$ & $13.8 \pm 1.1$ & $13.6 \pm 0.3$ & 24 \\
\hline P02538 & Keratin, type II cytoskeletal 6 & KRT6 & $14.1 \pm 0.1$ & $14.5 \pm 1.5$ & $13.1 \pm 0$ & 25 \\
\hline P35527 & Keratin, type I cytoskeletal 9 & KRT9 & $17 \pm 0$ & $15.6 \pm 1.2$ & $16.5 \pm 0.2$ & 16 \\
\hline
\end{tabular}


Enrichment analysis using the KEGG database revealed significant participation of detected proteins (ACTG1, TUBA1C, TUBA4A, TUBB, TUBB8, and YWHAZ) in pathogenic E. coli infection. Additionaly, dermcidin was detected in the R0 group, which normally displays antimicrobial activity and is highly effective against E.coli, E. faecalis, S. aureus, and C. albicans [40]. As well as KRT1 and $K R T 6 A, D C D$ takes part in humoral immune response. Presumably, the presence of these proteins in EBC suggest changes in microbial composition. This assumption was confirmed by a microbial composition analysis. The microflora of the studied biotopes (mouth, dental plaque, tongue, and cheek) was represented by micro-organisms of the normal flora (Gram-positive micro-organisms). The highest level of microbial contamination was revealed during the spaceflight. A high presence of E. coli was also observed in samples taken in the middle of a flight. In some cases, the presence of methicillin sensitive $S$. aureus was observed at $R+7$ (Table 2). Subsequently, during the rehabilitation period, the quantitative and species composition of microflora was normalized.

The experimental data correlated well with previous results. The cosmonauts' microbiocenoses on the first day after landing have been characterized by changes in the number of opportunistic pathogenic enterobacteria, clostridia, and lactobacilli ( $p$-value $>0.01, p$-value $>0.05, p$-value $>0.05$, respectively) [41]. In addition, dysbacteriosis have been recorded in the crew of the "Salyut" and "Mir" space stations after long-term space flights [41]. Shifts in microbial composition have also been detected during ground-based experiments. During a dry immersion experiment, the increase of bacterial colony-forming units (CFU) of conditionally pathogenic strains (S. aureus and enterobacterium spp., bacillus spp.) and decrease of symbiotic microflora (neiseria spp. and corinobacterioum spp.) were detected [42].

Pathways enrichment analysis (using the GO processes and pathways database) showed that the majority of $\mathrm{R} 0$ proteins participate in innate immune system processes and neutrophil degranulation. The immunochemical analysis of gingival fluid in the examined test subjects showed a decrease in the level of immunoglobulins ( $\operatorname{IgA}$, $\operatorname{IgA}$, and $\operatorname{IgM}$ ). A decrease in the $\operatorname{Ig} \mathrm{A}$ level may indicate the possibility of an inflammatory process in the periodontal tissues [43].

Some proteins also take part in keratinization (CASP14, DSG1, DSP, JUP, KRT6B, PKP1, SFN, $T G M 1$, and TGM3). In previous studies cytoskeleton keratins were shown as to be main proteins in the EBC of healthy peoples $[44,45]$. Some of them are also associated with different pathologies of the respiratory system such as pneumonia and lung cancer [37,38,46]. Due to Protein Atlas, keratins $K R T 1, K R T$ 2, KRT 9, and KRT 10 have epidermal origin and can contaminate samples during sample preparation. In previous studies, we have suggested keratins of EBC to belong to proteins circulating in the ambient air $[19,44]$. Almost every protein detected in EBC samples during background and in $\mathrm{R}+7$ groups is typical for EBC, despite the conditions of the lung system. The keratins detected in each group are presented in Table 1. A two-sample Welch's $t$-test was applied to identify the significantly changed proteins between the study groups. KRT2 increased and KRT9 decreased their respective levels after landing (Figure 2). In addition to their functions keratins are involve in cell signaling, communicating with extracellular matrix (ECM) components through desmosomes and hemidesmosomes [39]. 
Table 2. List of Micro-organisms of selected biotopes (mouth, dental plaque, tongue, and cheek) collected from cosmonauts. Colony-forming units (CFU) are presented.

\begin{tabular}{|c|c|c|}
\hline Biotopes & Micro-Organisms & CFU \\
\hline \multicolumn{3}{|c|}{45 days before spaceflight } \\
\hline Mouth & $\begin{array}{c}\text { Enterobacterium sp. } \\
\text { Enterococcus sp. }\end{array}$ & $\begin{array}{l}10^{7} \\
10^{4}\end{array}$ \\
\hline Dental plaque & $\begin{array}{l}\text { Streptococcus sp. } \\
\text { Enterobacterium sp. }\end{array}$ & $\begin{array}{l}10^{2} \\
10^{5}\end{array}$ \\
\hline Tongue & $\begin{array}{c}\text { Enterobacterium sp } \\
\text { Streptococcus sp. } \\
\text { Enterococcus sp. }\end{array}$ & $\begin{array}{l}10^{3} \\
10^{2} \\
10^{4}\end{array}$ \\
\hline Cheek & Staphylococcus sp. & $10^{4}-10^{5}$ \\
\hline \multicolumn{3}{|c|}{1 day before spaceflight } \\
\hline $\begin{array}{l}\text { Dental plaque } \\
\text { Tongue } \\
\text { Cheek }\end{array}$ & $\begin{array}{l}\text { Staphylococcus sp. } \\
\text { Enterococcus sp. } \\
\text { Staphylococcus sp. }\end{array}$ & $\begin{array}{l}10^{2} \\
10^{6} \\
10^{4}\end{array}$ \\
\hline \multicolumn{3}{|c|}{ During the spaceflight } \\
\hline $\begin{array}{c}\text { Mouth } \\
\text { Dental plaque }\end{array}$ & $\begin{array}{l}\text { Staphylococcus sp. } \\
\text { Staphylococcus sp. }\end{array}$ & $\begin{array}{c}10^{2} \\
10^{3}-10^{7}\end{array}$ \\
\hline Tongue & $\begin{array}{c}\text { Staphylococcus sp. } \\
\text { E.coli }\end{array}$ & $\begin{array}{l}10^{2} \\
10^{7}\end{array}$ \\
\hline Cheek & Staphylococcus sp. & $\sim 10^{1}$ \\
\hline \multicolumn{3}{|c|}{ Immediately after landing (R0) } \\
\hline Mouth & $\begin{array}{l}\text { Enterococcus sp. } \\
\text { Staphylococcus sp. }\end{array}$ & $\begin{array}{c}10^{1}-10^{6} \\
10^{1}\end{array}$ \\
\hline Dental plaque & $\begin{array}{l}\text { Enterococcus sp. } \\
\text { Staphylococcus sp. }\end{array}$ & $\begin{array}{c}10^{3}-10^{6} \\
10^{3}\end{array}$ \\
\hline Tongue & $\begin{array}{l}\text { Staphylococcus sp. } \\
\text { Enterococcus sp. }\end{array}$ & $\begin{array}{l}10^{3} \\
10^{3}\end{array}$ \\
\hline Cheek & Staphylococcus sp. & $\sim 10^{3}$ \\
\hline \multicolumn{3}{|c|}{7 day after landing $(\mathrm{R}+7)$} \\
\hline Mouth & $\begin{array}{l}\text { Enterococcus sp. } \\
\quad \text { S. Aureus }\end{array}$ & $\begin{array}{c}10^{3}-10^{5} \\
10^{4} \text { Met S }\end{array}$ \\
\hline Dental plaque & $\begin{array}{l}\text { Staphylococcus sp. } \\
\text { Enterococcus sp. }\end{array}$ & $\begin{array}{l}10^{1} \\
10^{5}\end{array}$ \\
\hline Tongue & $\begin{array}{l}\text { Enterococcus sp. } \\
\text { S. Aureus }\end{array}$ & $\begin{array}{c}10^{5}-10^{8} \\
10^{7} \text { Met S. }\end{array}$ \\
\hline Cheek & $\begin{array}{l}\text { Staphylococcus sp. } \\
\text { S. Aureus }\end{array}$ & $\begin{array}{c}10^{1}-10^{6} \\
10^{4} \text { Met S }\end{array}$ \\
\hline
\end{tabular}


A)

KRT9

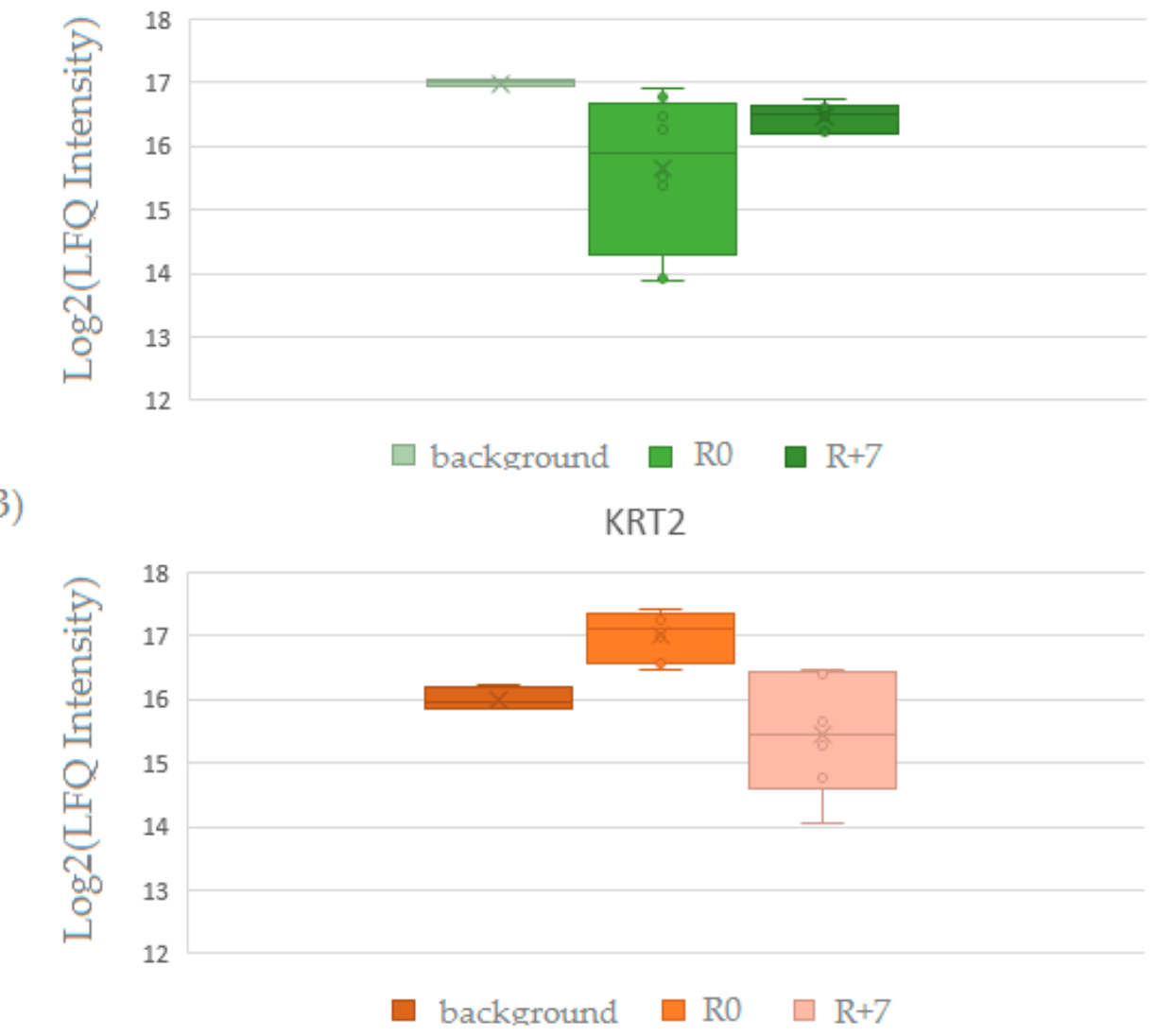

Figure 2. The label-free quantification (LFQ) intensity box plot for KRT9 (A) and KRT2 (B) proteins which changed their levels after landing, with respect to the background. The LFQ values are plotted on a $\log 2(x)$ scale along the vertical axis.

Previously we showed that overexpression of stress- or stimulus-associated proteins can be detected in urine on the 1st day after landing [13]. Most of the urine significant proteins that are associated with stress factors returns to its preflight levels up to the 7th day. On other hand, EBC and blood plasma proteome analysis revealed significantly changing proteins associated with the immune response. It is worth noting that plasma proteome changes due to the space flight correlates with results of ground based experiments such as head-down bed rest (HDBR) and dry immersion experiments [47].

In general, the results of the study are in favor of further considering EBC as a subject for the non-invasive monitoring of systemic physiological changes during spaceflights, and analysis of a larger number of samples seems highly appropriate. Among other things, the obtained data may be important for the modernization of medical approaches in relation to extreme conditions.

\section{Materials and Methods}

\subsection{Samples Collection}

The study was performed within the "Protokon" experiment. It included five Russian cosmonauts of 38-62 years of age (the average age was 45.5 years; four males and one female). The biological samples were collected one month before long-term (169-199 day) spaceflight (background) at the Yu. A. Gagarin Research and Test Cosmonaut Training Center, immediately after landing of the landing modules in the field (R0), and on the seventh day after landing as a part of a medical examination ( $R+7)$. The EBC study was approved (Code «EBC proteome», date 06 March 2017) by the Ethics Committee of the Institute of Biomedical Problems, Russian Academy of Sciences/Physiology Section of the Russian 
Bioethics Committee Russian Federation National Commission for UNESCO and Human Research Multilateral Review Board, NASA, Houston, TX, USA. All donors signed the informed consent for participation in the study.

The EBC was collected using a portable RTube device [48]. During EBC collection, the cosmonaut breathed quietly, for 10-15 min, through a special mouthpiece with a salivary trap, and the exhaled airflow was diverted through a Teflon or polypropylene tube inside a cooling container. Immediately after collection samples were transported at $-20{ }^{\circ} \mathrm{C}$ and stored at $-80{ }^{\circ} \mathrm{C}$ until use. The sample preparation for LC-MS analysis included freeze-drying and selective tryptic hydrolysis at $37^{\circ} \mathrm{C}$ for $17 \mathrm{~h}$ as previously discussed [49].

\subsection{LC-MS/MS Proteomic Analysis}

The tryptic peptide fraction (injection volume $1 \mu \mathrm{L}$ ) was analyzed in triplicate on a nano-HPLC Dionex Ultimate3000 system (Thermo Fisher Scientific, Waltham, MA, USA) coupled to a TiMS TOF mass spectrometry system (Bruker Daltonics, Bremen, Germany) using a captive spray ion source (positive ion mode, $1600 \mathrm{~V}$ ) (Bruker Daltonics, Bremen, Germany). HPLC separation was performed on a C18 capillary column $(25 \mathrm{~cm} \times 75 \mu \mathrm{m} \times 1.6 \mu \mathrm{m})$ (Ion Optics, Parkville, Australia) at a flow rate of $0.4 \mu \mathrm{L} / \mathrm{min}$ by gradient elution. The mobile phase $\mathrm{A}$ was $0.1 \%$ formic acid in water and mobile phase $\mathrm{B}$ was $0.1 \%$ formic acid in acetonitrile. The separation was carried out by a 40 min gradient from $3-90 \%$ of phase B.

\subsection{Data Analysis}

MS data were analyzed using the MaxQuant (v 1.6.5) [50] program against the SwissProt Human database with an initial precursor mass error of $70 \mathrm{ppm}$. The minimum peptide length for identification was set to seven amino acids; the match between the runs option was activated. The cutoff false discovery rate (FDR) for proteins and peptides was set to 0.01 (1\% FDR). Label-free quantitative analysis was performed in order to determine the significantly changed proteins. Quantification of peptides was recognized on the basis of mass and retention time but identified in other LC-MS/MS runs. Proteins quantification was carried out using the label-free quantification (LFQ) intensities of peptides across all samples and represented by a normalized intensity profile generated according to the specific algorithms. Protein-protein interactions were analyzed using the STRING database (v 11.0). The minimum coefficient of interaction score was 0.4 ; the PPI enrichment $p$-value was $<1.0 \times 10^{-16}$. The interactions included physical and functional associations derived from computational prediction, automated text mining, co-expression databases and genomic context prediction aggregated from other databases [51]. Protein categorical annotations were derived from GeneOntology using the SwissProt Human database. The mass spectrometric proteomic data were deposited into the ProteomeXchange Consortium through the PRIDE [49] partner repository.

\subsection{Collection of Microbiological Samples}

The biological samples for microbial analysis were collected 45 days and 1 day before spaceflight, in the middle of the spaceflight (second half) immediately after landing (R0) and 7 days after flight $(\mathrm{R}+7)$. Microbial samples collection was performed using sterile fluoroplastic tubes with tampons. The test tube contained a capillary with a preservative which moistened the swab and ensured the preservation of the initial microflora composition for up to 5 days. Bacteria were grown (incubated for $48 \mathrm{~h}$ at $37^{\circ} \mathrm{C}$ ) using the following culture media: blood agar (to determine the total microbial number); endo agar (to quantify the growth of Gram-negative rods); mannitol-salt agar (for quantitative assessment of staphylococcus growth); and saburo agar (to quantify the growth of yeast and yeast-like micro-organisms).

Supplementary Materials: Supplementary materials can be found at http://www.mdpi.com/1422-0067/20/18/ 4518/s1. All LC-MS/MS and proteomic data are available via ProteomeXchange with identifier PXD014191. 
Author Contributions: Conceptualization, I.M.L., S.D.V. and E.N.N.; Funding acquisition, I.M.L., S.D.V., I.A.P. and E.N.N.; Investigation, A.S.K., A.M.R., A.G.B., K.F., and I.A.P.; Methodology, A.S.K., A.M.R., K.F., N.V.Z., V.K.I., Z.O.S., A.I.S. and I.A.P.; Project administration, I.M.L., A.V.P., A.S.K., A.M.R. and E.N.N.; Resources, I.A.P., I.M.L., S.D.V. and E.N.N.; Software, A.G.B., K.F.; Supervision, A.V.P., A.S.K., A.M.R. and L.K.P.; Writing-original draft, A.G.B., A.M.R., K.F. and A.S.K.; Writing-review \& editing, A.S.K., L.K.P. and I.M.L.

Acknowledgments: The work was carried out within the framework of the basic Russian Academy of Sciences themes 64.1 and 65.3 for 2013-2020 years. The part of the research related to EBC proteome analysis by high-resolution mass spectrometry measurements was supported by the Russian Foundation for Basic Research project no. 18-29-09158 MK. For sample analysis, we used instruments of the Core Facility of the Emanuel Institute of Biochemical Physics RAS “New Materials and Technologies", Institute of Biomedical Problems RAS and Skolkovo Institute of Science and Technology.

Conflicts of Interest: The authors declare no potential conflicts of interest with respect to the research, authorship, and/or publication of this article.

\section{References}

1. Stein, T.P. Weight, muscle and bone loss during space flight: Another perspective. Eur. J. Appl. Physiol. 2013, 113, 2171-2181. [CrossRef] [PubMed]

2. Terada, M.; Seki, M.; Takahashi, R.; Yamada, S.; Higashibata, A.; Majima, H.J.; Sudoh, M.; Mukai, C.; Ishioka, N. Effects of a closed space environment on gene expression in hair follicles of astronauts in the International Space Station. PLOS ONE 2016, 11, 1-17.

3. Meigal, A. Interplanetary space flight compared with fetal/neonatal motor strategy: Theoretical and practical implications. Pathophysiology 2012, 19, 269-276. [CrossRef] [PubMed]

4. Kononikhin, A.S.; Starodubtseva, N.L.; Pastushkova, L.K.; Kashirina, D.N.; Fedorchenko, K.Y.; Brhozovsky, A.G.; Popov, I.A.; Larina, I.M.; Nikolaev, E.N. Spaceflight induced changes in the human proteome. Expert. Rev. Proteom. 2017, 14, 15-29. [CrossRef] [PubMed]

5. Barcellos-Hoff, M.H.; Blakely, E.A.; Burma, S.; Fornace, A.J.; Gerson, S.; Hlatky, L.; Kirsch, D.G.; Luderer, U.; Shay, J.; Wang, Y.; et al. Concepts and challenges in cancer risk prediction for the space radiation environment. Life Sci. Sp. Res. 2015, 6, 92-103. [CrossRef] [PubMed]

6. Reynolds, R.J.; Day, S.M. Mortality among U.S. astronauts: 1980-2009. Aviat. Sp. Environ. Med. 2010, 81, 1024-1027. [CrossRef]

7. Boerma, M. Space radiation and cardiovascular disease risk. World J. Cardiol. 2015, 7, 882. [CrossRef]

8. Yamaguchi, N.; Roberts, M.; Castro, S.; Oubre, C.; Makimura, K.; Leys, N.; Grohmann, E.; Sugita, T.; Ichijo, T.; Nasu, M. Microbial Monitoring of Crewed Habitats in Space-Current Status and Future Perspectives. Microbes Env. 2014, 29, 250-260. [CrossRef]

9. Ulbrich, C.; Wehland, M.; Pietsch, J.; Aleshcheva, G.; Wise, P.; Van Loon, J.; Magnusson, N.; Infanger, M.; Grosse, J.; Eilles, C.; et al. The impact of simulated and real microgravity on bone cells and mesenchymal stem cells. Biomed. Res. Int. 2014, 2014. [CrossRef]

10. Draganov, D.I.; Teiber, J.F.; Speelman, A.; Osawa, Y.; Sunahara, R.; La Du, B.N. Human paraoxonases (PON1, PON2, and PON3) are lactonases with overlapping and distinct substrate specificities. J. Lipid Res. 2005, 46, 1239-1247. [CrossRef]

11. Rizzo, A.M.; Altiero, T.; Corsetto, P.A.; Montorfano, G.; Guidetti, R.; Rebecchi, L. Space flight effects on antioxidant molecules in dry tardigrades: The TARDIKISS experiment. Biomed. Res. Int. 2015, 2015. [CrossRef] [PubMed]

12. Grimm, D.; Pietsch, J.; Richter, M.; Peter, W.; Strauch, S.M.; Lebert, M.; Magnusson, N.E.; Wise5, P.; Bauer, J. The impact of microgravity-based proteomics research. Expert Rev. Proteom. 2014, 11, 465-475. [CrossRef] [PubMed]

13. Brzhozovskiy, A.; Kononikhin, A.; Indeykina, M.; Pastushkova, L.; Popov, I.A.; Nikolaev, E.N.; Larina, I.M. Label-free study of cosmonaut's urinary proteome changes after long-duration spaceflights. Eur. J. Mass Spectrom. 2017, 23, 225-229. [CrossRef] [PubMed]

14. Liu, X.; Zheng, P.; Zhao, X.; Zhang, Y.; Hu, C.; Li, J.; Zhao, J.; Zhou, J.; Xie, P.; Xu, G. Discovery and validation of plasma biomarkers for major depressive disorder classification based on liquid chromatography-mass spectrometry. J. Proteome Res. 2015, 14, 2322-2330. [CrossRef] [PubMed] 
15. Corradi, M.; Pignatti, P.; Manini, P.; Andreoli, R.; Goldoni, M.; Poppa, M.; Moscatto, G.; Balbi, B.; Mutti, A. Comparison between exhaled and sputum oxidative stress biomarkers in chronic airway inflammation. Eur. Respir. J. 2004, 24, 1011-1017. [CrossRef] [PubMed]

16. Kononikhin, A.S.; Starodubtseva, N.L.; Chagovets, V.V.; Ryndin, A.Y.; Burov, A.A.; Popov, I.A.; Bugrova, A.E.; Dautov, R.A.; Tokareva, A.O.; Podurovskaya, Y.L.; et al. Exhaled breath condensate analysis from intubated newborns by nano-HPLC coupled to high resolution MS. J. Chromatogr. B Anal. Technol. Biomed. Life Sci. 2017, 1047, 97-105. [CrossRef] [PubMed]

17. Hunt, J. Exhaled breath condensate: An evolving tool for noninvasive evaluation of lung disease. J. Allergy Clin. Immunol. 2002, 110, 28-34. [CrossRef]

18. Horváth, I.; Hunt, J.; Barnes, P.J.; Alving, K.; Antczak, A.; Baraldi, E.; Becher, G.; van Beurden, W.J.C.; Corradi, M.; Dekhuijzen, R.; et al. Exhaled breath condensate: Methodological recommendations and unresolved questions. Eur. Respir. J. 2005, 26, 523-548. [CrossRef]

19. Kurova, V.S.; Anaev, E.C.; Kononikhin, A.S.; Popov, I.A.; Fedorchenko, K.Y.; Nikolaev, E.N.; Varfolomeev, S.D.; Chuchalin, A.G. Mass spectrometric monitoring of exhaled breath condensate proteome of a patient after lung transplantation. Russ. Chem. Bull. Int. Ed. 2010, 59, 292-296. [CrossRef]

20. Phillips, M.; Cataneo, R.N.; Chaturvedi, A.; Kaplan, P.D.; Libardoni, M.; Mundada, M.; Patel, U.; Zhang, X. Detection of an Extended Human Volatome with Comprehensive Two-Dimensional Gas Chromatography Time-of-Flight Mass Spectrometry. PLoS ONE 2013, 8, 1-8. [CrossRef]

21. Lourenço, C.; Turner, C. Breath Analysis in Disease Diagnosis: Methodological Considerations and Applications. Metabolites 2014, 4, 465-498.

22. Corradi, M.; Montuschi, P.; Donnelly, L.E.; Pesci, A.; Kharitonov, S.A.; Barnes, P.J. Increased nitrosothiols in exhaled breath condensate in inflammatory airway diseases. Am. J. Respir. Crit. Care Med. 2001, 163, 854-858. [CrossRef] [PubMed]

23. Ho, L.P.; Innes, J.A.; Greening, A.P. Nitrite levels in breath condensate of patients with cystic. Thorax 1998, 53, 680-684. [CrossRef] [PubMed]

24. Balint, B.; Donnelly, L.E.; Hanazawa, T.; Kharitonov, S.A.; Barnes, P.J. Increased nitric oxide metabolites in exhaled breath condensate after exposure to tobacco smoke. Thorax 2001, 56, 456-461. [CrossRef] [PubMed]

25. Kharitonov, S.; Yates, D.; Barnes, P. Inhaled Glucocorticoids Decrease Nitric Oxide in Exhaled Air of Asthmatic Patients. Am. J. Respir. Crit. Care Med. 1996, 153. [CrossRef] [PubMed]

26. Loukides, S.; Horvath, I.; Wodehouse, T.; Cole, P.J.; Barnes, P.J. Brief Communications Elevated Levels of Expired Breath Hydrogen Peroxide in Bronchiectasis. Crit. Care Med. 1998, 158, 991-994. [CrossRef]

27. Jöbsis, Q.; Raatgeep, H.C.; Schellekens, S.L.; Kroesbergen, A.; Hop, W.C.J.; De Jongste, J.C. Hydrogen peroxide and nitric oxide in exhaled air of children with cystic fibrosis during antibiotic treatment. Eur. Respir. J. 2000, 16, 95-100. [CrossRef]

28. Bast, A.; van Herwaarden, C.L.; Dekker, I.; Dekhuijzen, P.N.; Aarts, L.P.; Aben, K.K.; Wielders, P.L. Increased exhalation of hydrogen peroxide in patients with stable and unstable chronic obstructive pulmonary disease. Am. J. Respir. Crit. Care Med. 2013, 154, 813-816.

29. Dohlman, A.W.; Black, H.R.; Royall, J.A. Expired Breath Hydrogen Peroxide Is a Marker of Acute Airway Inflammation in Pediatric Patients with Asthma. Am. Rev. Respir. Dis. 2011, 148, 955-960. [CrossRef]

30. Sanak, M.; Gielicz, A.; Nagraba, K.; Kaszuba, M.; Kumik, J.; Szczeklik, A. Targeted eicosanoids lipidomics of exhaled breath condensate in healthy subjects. J. Chromatogr. B Anal. Technol. Biomed. Life Sci. 2010, 878, 1796-1800. [CrossRef]

31. Fernández-Peralbo, M.A.; Calderón Santiago, M.; Priego-Capote, F.; Luque De Castro, M.D. Study of exhaled breath condensate sample preparation for metabolomics analysis by LC-MS/MS in high resolution mode. Talanta 2015, 144, 1360-1369. [CrossRef] [PubMed]

32. Montuschi, P.; Collins, J.V.; Ciabattoni, G.; Lazzeri, N.; Corradi, M.; Kharitonov, S.A.; Barnes, P.J. Exhaled 8-isoprostane as an in vivo biomarker of lung oxidative stress in patients with COPD and healthy smokers. Am. J. Respir. Crit. Care Med. 2000, 162, 1175-1177. [CrossRef] [PubMed]

33. Ojoo, J.C.; Mulrennan, S.A.; Kastelik, J.A.; Morice, A.H.; Redington, A.E. Exhaled breath condensate pH and exhaled nitric oxide in allergic asthma and in cystic fibrosis. Thorax 2005, 60, 22-26. [CrossRef] [PubMed]

34. Vaughan, J.; Ngamtrakulpanit, L.; Pajewski, T.N.; Turner, R.; Nguyen, T.A.; Smith, A.; Urban, P.; Hom, S.; Gaston, B.; Hunt, J. Exhaled breath condensate $\mathrm{pH}$ is a robust and reproducible assay of airway acidity. Eur. Respir. J. 2003, 22, 889-894. [CrossRef] [PubMed] 
35. Walsh, B.K.; Davis, M.D.; Hunt, J.F.; Kheir, J.N.; Smallwood, C.D.; Arnold, J.H. The effects of lung recruitment maneuvers on exhaled breath condensate pH. J. Breath Res. 2015, 9, 036009. [CrossRef] [PubMed]

36. Kullmann, T.; Barta, I.; Csiszé, E.; Antus, B.; Horváth, I. Differential cytokine pattern in the exhaled breath of patients with lung cancer. Pathol. Oncol. Res. 2008, 14, 481-483. [CrossRef] [PubMed]

37. López-Sánchez, L.M.; Jurado-Gámez, B.; Feu-Collado, N.; Valverde, A.; Cañas, A.; Fernández-Rueda, J.L.; Aranda, E.; Rodríguez-Ariza, A. Exhaled breath condensate biomarkers for the early diagnosis of lung cancer using proteomics. Am. J. Physiol. Cell. Mol. Physiol. 2017, 313, L664-L676. [CrossRef]

38. Fedorchenko, K.Y.; Ryabokon, A.M.; Kononikhin, A.S.; Mitrofanov, S.I.; Barmin, V.V.; Pikina, O.V.; Anafiev, E.K.; Gaciok, I.V.; Popov, I.A.; Nikolaev, E.N.; et al. Early diagnostics of lung cancer based on analysis of protom of exhausted breath condensate. Moscow Univ. Bull. 2016, 57, 112-119.

39. Homberg, M.; Magin, T.M. Beyond Expectations: Novel Insights into Epidermal Keratin Function and Regulation, 1st ed.; Elsevier Inc.: Amsterdam, The Netherlands, 2014; Volume 311, pp. 265-306.

40. Lee Motoyama, J.P.; Kim-Motoyama, H.; Kim, P.; Nakagama, H.; Miyagawa, K.; Suzuki, K. Identification of dermcidin in human gestational tissue and characterization of its proteolytic activity. Biochem. Biophys. Res. Commun. 2007, 357, 828-833. [CrossRef]

41. Ilyin, V.K. Microbiological status of cosmonauts during orbital spaceflights on Salyut and Mir orbital stations. Acta Astronaut. 2005, 56, 839-850. [CrossRef]

42. Ilyin, V.K.; Solovieva, Z.O.; Skedina, M.A.; Papp, L.G. Evaluation of the effectiveness of automated analysis of the state of microflora of testers in conditions of 7 daily "dry" immersion. Aviakosm Ekol. Med. 2011, $45,43-46$.

43. Ilyin, V.K.; Shumilina, G.A.; Soloviev, Z.O.; Nosovsky, A.M.; Kaminskaya, E.V. Some indicators of the condition of the oral cavity and teeth of the cosmonauts during flights at the international space station. Aviakosm Ekol. Med. 2016, 50, 25-30.

44. Hoffmann, H.J.; Tabaksblat, L.M.; Enghild, J.J.; Dahl, R. Human skin keratins are the major proteins in exhaled breath condensate. Eur. Respir. J. 2008, 31, 380-384. [CrossRef]

45. Kurova, V.S.; Anaev, E.C.; Kononikhin, A.S.; Fedorchenko, K.Y.; Popov, I.A.; Kalupov, T.L.; Bratanov, D.O.; Nikolaev, E.N.; Varfolomeev, S.D. Proteomics of exhaled breath: Methodological nuances and pitfalls. Clin. Chem. Lab. Med. 2009, 47, 706-712. [CrossRef]

46. Kononikhin, A.S.; Fedorchenko, K.Y.; Ryabokon, A.M.; Starodubtseva, N.L.; Popov, I.A.; Zavialova, M.G.; Anaev, E.C.; Chuchalin, A.G.; Varfolomeev, S.D.; Nikolaev, E.N. Proteomic analysis of exhaled breath condensate for diagnosis of pathologies of the respiratory system. Biomeditsinskaya Khimiya 2015, 61, 777-780. [CrossRef]

47. Brzhozovskiy, A.G.; Kononikhin, A.S.; Pastushkova, L.C.; Larina, I.M.; Nikolaev, E.N. The Effects of Spaceflight Factors on the Human Plasma Proteome, Including Both Real Space Missions and Ground-Based Experiments. Int. J. Mol. Sci. 2019, 20, 3194. [CrossRef]

48. Konstantinidi, E.M.; Lappas, A.S.; Tzortzi, A.S.; Behrakis, P.K. Exhaled Breath Condensate: Technical and Diagnostic Aspects. Sci. World J. 2015, 2015, 435160. [CrossRef]

49. Vizca, J.A.; Csordas, A.; Griss, J.; Lavidas, I.; Mayer, G.; Perez-riverol, Y.; Reisinger, F.; Ternent, T.; Xu, Q.; Wang, R.; et al. 2016 update of the PRIDE database and its related tools. Nucleic. Acids Res. 2016, 44, 447-456. [CrossRef]

50. Tyanova, S.; Temu, T.; Cox, J. The MaxQuant computational platform for mass spectrometry-based shotgun proteomics. Nat. Protoc. 2016, 11, 2301-2319. [CrossRef]

51. Von Mering, C.; Huynen, M.; Jaeggi, D.; Schmidt, S.; Bork, P.; Snel, B. STRING: A database of predicted functional associations between proteins. Nucleic Acids Res. 2003, 31, 258-261. [CrossRef]

(C) 2019 by the authors. Licensee MDPI, Basel, Switzerland. This article is an open access article distributed under the terms and conditions of the Creative Commons Attribution (CC BY) license (http://creativecommons.org/licenses/by/4.0/). 